\title{
Variant Philadelphia translocations with different breakpoints in six chronic myeloid leukemia patients
}

\section{Altı Kronik miyeloid lösemi olgusunda farklı kırık noktalı varyant Philadelphia translokasyonlart}

\author{
Dilhan Kuru ${ }^{1}$, Yelda Tarkan Argüden ${ }^{1}$, Muhlis Cem Ar ${ }^{3}$, Ayşe Çırakoğlu' ${ }^{1}$, \\ SSeniz Öngören ${ }^{3}$, Şükriye Yılmaz ${ }^{1}$, Ahmet Emre Eşkazan ${ }^{3}$, Ayhan Deviren², \\ Teoman Soysal ${ }^{3}$, Seniha Hacıhanefioğlu ${ }^{2}$, Birsen Ülkü ${ }^{3}$ \\ ${ }^{1}$ Department of Medical Biology, Cerrahpaşa Faculty of Medicine, Istanbul University, Istanbul, Turkey \\ ${ }^{2}$ Department of Medical Genetics, Cerrahpaşa Faculty of Medicine, Istanbul University, Istanbul, Turkey \\ ${ }^{3}$ Department of Internal Medicine, Division of Hematology, Cerrahpaşa Faculty of Medicine, İstanbul University, \\ Istanbul, Turkey
}

\begin{abstract}
Objective: The Philadelphia ( $\mathrm{Ph})$ chromosome, consisting of the $t(9 ; 22)(\mathrm{q} 34 ; \mathrm{q} 11)$ translocation, is observed in $\sim 90 \%$ of patients with chronic myeloid leukemia (CML). Variant $\mathrm{Ph}$ translocations are observed in 5\%-10\% of CML patients. In variant translocations 3 and possibly more chromosomes are involved. Herein we report $6 \mathrm{CML}$ patients with variant $\mathrm{Ph}$ translocations.

Materials and Methods: Bone marrow samples were examined using conventional cytogenetic meth ods. Fluorescence in situ hybridization (FISH) with whole-chromosome paints and BCR-ABL 1D probes were used to confirm and/or complement the findings, and identify rearrangements beyond the resolution of conventional cytogenetic methods.

Results: Variant $\mathrm{Ph}$ translocations in the 6 patients were as follows: $t(7 ; 22)(p 22 ; q 11), t(9 ; 22 ; 15)$ $(q 34 ; q 11 ; q 22), t(15 ; 22)(p 11 ; q 11), t(1 ; 9 ; 22 ; 3)(q 24 ; q 34 ; q 11 ; q 21), t(12 ; 22)(p 13 ; q 11)$, and $t(4 ; 8 ; 9 ; 22)$ (q11;q13;q34;q11).

Conclusion: Among the patients, 3 had simple and 3 had complex variant $\mathrm{Ph}$ translocations. Two of the presented cases had variant $\mathrm{Ph}$ chromosomes not previously described, 1 of which had a new complex $\mathrm{Ph}$ translocation involving chromosomes $1,3,9,22$, and $\mathrm{t}(1 ; 9 ; 22 ; 3)(\mathrm{q} 24 ; \mathrm{q} 34 ; \mathrm{q} 11 ; \mathrm{q} 21)$ apart from a clone with a classical $\mathrm{Ph}$, and the other case had variant $\mathrm{Ph}$ translocation with chromosomes 4, 8, 9, and 22 , and $t(4 ; 8 ; 9 ; 22)(q 11 ; q 13 ; q 34 ; q 11)$ full complex translocation. Number of studies reported that some patients with variant $\mathrm{Ph}$ translocation were poor responders to imatinib. All of our patients with variant $\mathrm{Ph}$ translocations had suboptimal responses to imatinib, denoting a poor prognosis also. Variant $\mathrm{Ph}$ translocations may be important as they are associated with prognosis and therapy for CML patients. (Turk J Hematol 2011; 28: 186-92)

Key words: Chronic myeloid leukemia (CML), variant Ph chromosome, cytogenetics, fluorescence in situ hybridization (FISH)
\end{abstract}

Received: June 25, 2010

Accepted: August 19, 2010

Address for Correspondence: Dr. Dilhan Kuru, Department of Medical Biology, Cerrahpaşa Faculty of Medicine, İstanbul University, İstanbul, Turkey Phone: +90 21241430 34 E-mail: dilhank@istanbul.edu.tr 


\section{Özet}

Amaç: $t(9 ; 22)(q 34 ; q 11)$ sonucu oluşan Philadelphia (Ph) kromozomu, kronik miyeloid lösemi (KML) olgularının \%90' dan fazlasında gözlenir. KML hastalarının \%5-10 unda varyant $\mathrm{Ph}$ translokasyonları bulunur. Varyant translokasyonlar üç ve daha fazla kromozom içerebilmektedir. Bu çalışmada varyant $\mathrm{Ph}$ translokasyonlu $6 \mathrm{KML}$ olgusu sunulmaktadir.

Yöntemler ve Gereçler: Kemik iliği örnekleri konvansiyonel sitogenetik kullanılarak incelendi; BCRABL 1D problarının kullanıldığı Floresan İn Situ Hibridizasyon (FISH) yöntemi bulguların doğrulanması ve konvansiyonel sitogenetik yöntemlerinin tespit etmekte yetersiz kaldığı yeniden düzenlemelerin tanımlanması amaciyla uyguland.

Bulgular: Çalışmada yer alan 6 hastanın varyant $P h$ translokasyonları: $t(7 ; 22)(p 22 ; q 11), t(9 ; 22 ; 15)$ $(\mathrm{q} 34 ; \mathrm{q} 11 ; \mathrm{q} 22), \mathrm{t}(15 ; 22)(\mathrm{p} 11 ; \mathrm{q} 11), \mathrm{t}(1 ; 9 ; 22 ; 3)(\mathrm{q} 24 ; \mathrm{q} 34 ; \mathrm{q} 11 ; \mathrm{q} 21), \mathrm{t}(12 ; 22)(\mathrm{p} 13 ; \mathrm{q} 11)$ ve $\mathrm{t}(4 ; 8 ; 9 ; 22)$ (q11;q13;q34;q11) dir.

Sonuç: Úç olguda basit, 3 olguda ise karmaşık (kompleks) varyant Ph translokasyonları saptamış bulunuyoruz. Olgularımızın ikisi daha önce bildirilmeyen varyant $\mathrm{Ph}$ kromozomları taşıyorlardı. Bu olgulardan biri klasik Ph'lı bir klonun yanısıra 1, 9, 22 ve 3 numaralı kromozomları içeren t( $1 ; 9 ; 22 ; 3)$ (q24;q34;q11;q21) formüllü yeni bir kompleks $P h$ translokasyonuna; diğeri ise 4, 8, 9 ve 22 numaralı kromozomları içeren $t(4 ; 8 ; 9 ; 22)(q 11 ; q 13 ; q 34 ; q 11)$ kompleks translokasyonlu varyant Ph'ya sahiptiler. Varyant $\mathbf{P h}{ }^{\prime} \mathbf{} 6$ olgunun tümü kötü prognoza işaret eden yetersiz imatinib cevabı gösterdiler.

(Turk J Hematol 2011; 28: 186-92)

Anahtar kelimeler: Kronik myeloid lösemi (KML), varyant Philadelphia kromozomu, sitogenetik, floresan in situ hibridizasyon (FISH)

Kabul tarihi: 19 Ağustos 2010

\section{Introduction}

Chronic myeloid leukemia (CML) is a clonal myeloproliferative neoplasm arising from neoplastic transformation of a pluripotent stem cell. The Philadelphia $(\mathrm{Ph})$ chromosome, which is the result of $\mathrm{t}(9 ; 22)$ (q34; $\mathrm{q} 11)$, is observed in $\sim 90 \%$ of $\mathrm{CML}$ patients. The translocation leads to fusion of the proto-oncogene Abelson (ABL) and a particular DNA sequence known as breakpoint cluster region (BCR), thereby giving rise to 2 new chimeric genes 5' ABL-3' BCR on the derivative chromosome 9 and 5' BCR-3' ABL on the derivative chromosome 22. Variant $\mathrm{Ph}$ translocations have been observed in 5\%-10\% of CML patients [1]. These variant translocations may be simple or complex. Simple variant translocations occur when the deleted segment of $22 \mathrm{q}$ is translocated onto a chromosome other than chromosome 9. In complex translocations, 3 and possibly more chromosomes are involved $[2,3]$. In a few cases of variant $\mathrm{Ph}$ translocations the BCR-ABL fusion gene is located on chromosomal sites other than 22q11 [4].

More than 1 mechanism plays a role in the evolution of variant $\mathrm{Ph}$ translocation; it can originate secondary to simple Ph translocation or can arise simultaneously in a 3-way rearrangement. Different mechanisms involved in the formation of a variant translo- cation may have different clinical implications: a 2-step evolution might resemble a clonal evolution, whereas variant translocations that evolve simultaneously in a 3-way rearrangement may be similar to simple Ph translocation [5]. The clinical significance of variant $\mathrm{t}(9 ; 22)$ translocations is not clear [4].

In the present study bone marrow samples from 6 CML patients were examined using conventional cytogenetic methods, FISH with whole-chromosome paints, and BCR-ABL 1D probes to confirm and/or complement the findings, and identify rearrangements beyond the resolution of conventional cytogenetic methods. Additionally, 2 of the CML patients had new complex translocations; 1 between chromosomes 1, 3, 9, 22, and other between 4, 8, 9, and 22. Possible correlations between chromosome breakpoints other than 9 and 22 in these Ph variant tranlocations, and recent updates for the map locations of consistent cancer breakpoints, fragile sites, and oncogenes are discussed.

\section{Materials and Methods}

\section{Patients}

The study included 6 clinically diagnosed CML patients that were referred for cytogenetic analysis and had variant $\mathrm{Ph}$ translocations. Clinical features of the patients are shown in Table 1. 
Table 1. Clinical features of the patients

\begin{tabular}{|c|c|c|c|c|c|c|}
\hline Case & 1 & 2 & 3 & 4 & 5 & 6 \\
\hline Age/Sex & $39 / \mathrm{F}$ & $23 / \mathrm{M}$ & $52 / \mathrm{M}$ & $33 / \mathrm{F}$ & $60 / \mathrm{F}$ & $32 / \mathrm{M}$ \\
\hline Reason for referral & CML & CML & CML & CML & CML & CML \\
\hline $\begin{array}{l}\text { Splenomegaly } \\
\text { (cm below the costal margin) }\end{array}$ & 0 & NA & 0 & 15 & 0 & 25 \\
\hline Hemoglobin level (g/dL) & 9.7 & NA & 13.9 & 9,7 & 11 & 8,4 \\
\hline Platelet count $\left(\mathrm{mm}^{3}\right)$ & 360 & NA & 220 & 360 & 180 & 214 \\
\hline Leukocyte count $\left(\mathrm{mm}^{3}\right)$ & 75.4 & NA & 67.7 & 160 & 69,7 & 123,7 \\
\hline Blasts in PB (\%) & 1 & NA & 0 & 1 & 0 & 3 \\
\hline Sokal score & Low & NA & Low & Intermediate & Low & High \\
\hline Best cytogenetic response & PCR & NA & CCR & NCR & NCR & NCR \\
\hline Treatment & HU, IFN, IM & NA & HU, IFN,I M & HU, IFN, ARA-C, IM, D & HU, GL & HU, IM, D \\
\hline
\end{tabular}

NA: Not Available; F: Female; M: Male; PB: Peripheral Blood; HU: Hydroxyurea; INF: Interferon; ARA-C: Cytosine arabinoside; IM: Imatinib mesylate; D: Dasatinib; PCR: Partial cytogenetic response; CCR: Complete cytogenetic response; NCR: No cytogenetic response

\section{Cytogenetic and FISH analysis}

Bone marrow (BM) samples were used for cytogenetic and FISH analysis.

\section{Cytogenetics}

Cytogenetic analysis was performed on overnight and 24-h unstimulated BM cultures using standard procedures. The GTL (G-bands via trypsin using Leishman) banding technique [6] was applied to the slides, karyotypes were described according to the International System for Human Cytogenetic Nomenclature (2005) [7], and 15-20 metaphases were analyzed for each sample.

\section{FISH analysis}

Fresh slides were used for FISH analysis. Before hybridization the slides were pre-treated with pepsin, followed by post-fixation and denaturation. FISH analysis was performed according to the manufacturer's protocols. BCR-ABL1 rearrangement was examined using a BCR-ABL1 D-FISH probe (BCR: $500 \mathrm{~Kb}$ in red; ABL1: $600 \mathrm{~Kb}$ in green; Oncor, Inc., Gaithersburg, MD, USA).

FISH analyses using whole chromosome paint (WCP) probes to characterize only complex variant translocations in patients 2, 4 and 6.: for patient 2 painting probes for chromosomes 15 and 22 were digoxigenin labeled (WCP 15 and WCP 22; Oncor, Gaithersburg, MD, USA); for patient 4 painting probes for chromosomes 1, 9, and 22 (WCP 1, 9, and 22; XCP-MetaSystems); for patient
6 painting probes for chromosomes $4,8,9$, and 22 (WCP 4, 8, 9, and 22; XCP-MetaSystems and Cytocell). Fluorescence microscopy was performed with a Nikon E600 microscope with a triple-pass filter and a cooled monochrome CCD camera, using MacProbe FISH analysis software and a CytoVision Ultra system (Applied Imaging, Pittsburgh, PA).

\section{Results}

Variant $\mathrm{Ph}$ translocations were identified in all 6 patients using G-banding analysis, and were confirmed via FISH analysis. G-banding and FISH results are shown in Table 2.

Table 2. G-Banding and FISH results in the patients

\begin{tabular}{|c|c|c|c|}
\hline Patient & Karyotype & Probe & $\begin{array}{l}\text { Hybridization } \\
\text { pattern }\end{array}$ \\
\hline 1 & $46, \mathrm{XX}, \mathrm{t}(7 ; 22)(\mathrm{p} 22 ; \mathrm{q} 11)$ & $\begin{array}{l}\text { BCR-ABL1 } \\
\text { D-FISH }\end{array}$ & BCR-ABL (+) \\
\hline 2 & $\begin{array}{l}46, X Y, t(9 ; 22 ; 15) \\
\text { (q34;q11;q22) }\end{array}$ & WCP 15 and 22 & confirmed \\
\hline 3 & $\begin{array}{l}46, \mathrm{XY}, \mathrm{t}(13 ; 15)(\mathrm{p} 11 ; \mathrm{q} 13) \\
\mathrm{t}(15 ; 22)(\mathrm{p} 11 ; \mathrm{q} 11)\end{array}$ & $\begin{array}{l}\text { BCR-ABL1 } \\
\text { D-FISH }\end{array}$ & BCR-ABL $(+)$ \\
\hline 4 & $\begin{array}{l}\text { 46,XX,t(9;22)(q34;q11)/ } \\
46, \mathrm{XX}, \mathrm{t}(1 ; 9 ; 22 ; 3) \\
(\mathrm{q} 24 ; \mathrm{q} 34 ; \mathrm{q} 11 ; \mathrm{q} 21)\end{array}$ & $\begin{array}{l}\text { BCR-ABL1 } \\
\text { D-FISH } \\
\text { WCP 1, 9, } 22\end{array}$ & $\begin{array}{l}\text { BCR-ABL } \\
(+), \\
\text { confirmed }\end{array}$ \\
\hline 5 & $46, \mathrm{XX}, \mathrm{t}(12 ; 22)(\mathrm{p} 13 ; \mathrm{q} 11)$ & $\begin{array}{l}\text { BCR-ABL1 } \\
\text { D-FISH }\end{array}$ & BCR-ABL $(+)$ \\
\hline 6 & $\begin{array}{l}46, X Y, t(4 ; 8 ; 9 ; 22) \\
\text { (q11;q13;q34;q11) }\end{array}$ & $\begin{array}{l}\text { BCR-ABL1 } \\
\text { D-FISH } \\
\text { WCP } 4,8,9 \text {, } \\
\text { and } 22\end{array}$ & $\begin{array}{l}\text { BCR-ABL } \\
(+), \\
\text { confirmed }\end{array}$ \\
\hline
\end{tabular}




\section{Cytogenetics}

In all, 3 of the patients (1,3, and 5) had simple variant $\mathrm{Ph}$ translocations and 3 (2, 4, and 6) had complex translocations. Among the complex variant $\mathrm{Ph}$ translocations, 3 chromosomes were involved in 1 patient (2) and 4 chromosomes were involved in 2 patients ( 4 and 6). Clonal evolution was observed only in patient 4 ; there were 2 clones 1 with a classical $\mathrm{Ph}$ and 1 with $\mathrm{t}(1 ; 9 ; 22 ; 3)$ (q24;q34;q11;q21). The chromosomal breakpoints of the variant $\mathrm{Ph}$ translocations were $1 \mathrm{q} 24,3 \mathrm{q} 21$, 4q11, 7p22, 8q13, 12p13,15p11, and 15q22. In patient 3 additional clonal chromosomal changes along with variant $\mathrm{Ph}$ translocation were observed [t(13;15)(p11;q13)]. Partial G-banding karyotypes are presented in Figure 1.

\section{FISH analysis}

In 5 patients $(1,3,4,5$, and 6$)$ dual-color FISH with the use of the BCR and ABL probes showed the BCR-ABL fusion gene on the Ph chromosome. In patient 2 BCR and ABL probes could not be used due to insufficient material. With the WCP probes involvement of chromosomes other than 9 and 22 in the complex variant translocations were confirmed in patients 2, 4, and 6. FISH images are shown in Figure 2.

\section{Discussion}

In the present study chromosomal breakpoints of the variant $\mathrm{Ph}$ translocations other than classical 9 and 22 breakpoints were 1q24, 3q21, 4q11, 7p22, $8 q 13,12 p 13,15 p 11$, and 15q22. All 8 breakpoints observed in the 6 patients are listed as variant $\mathrm{Ph}$ translocations in the Mitelman database (http:// www.cgap.nci.nih.gov/Chromosomes/Mitelman; updated 23 February 2009) [8]. Among the chromosomes that constituted variant $\mathrm{Ph}$ translocations in the presented patients, those that were previously described are shown in Table 3 .

It was reported that breakpoints involved in variant $\mathrm{Ph}$ translocations are primarily located in lightstaining bands [2]. Apart from 1q24, the breakpoints observed in the present study were also in lightstaining bands. Most of the breakpoints observed in the present study harbor genes known to be associated with neoplasia. GPA33 in 1q24, DIRC2 and HSPBAP1 in 3q21, BTL in 4q11, ETV6 in 12p13, and PML in 15q22 genes are implicated in different leu-

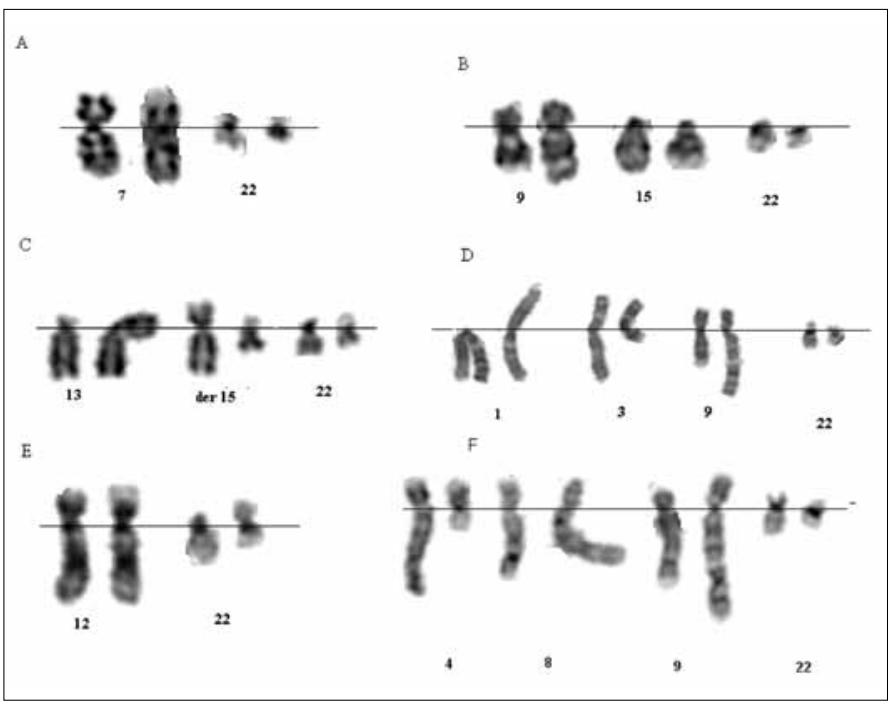

Figure 1. Partial G-banding karyotypes in the 6 patients. A. Patient 1: $\mathrm{t}(7 ; 22)(\mathrm{p} 22 ; \mathrm{q} 11)$. B. Patient 2 : $\mathrm{t}(9 ; 22 ; 15)(\mathrm{q} 34 ; \mathrm{q} 11 ; \mathrm{q} 22)$. C. Patient $3: \mathrm{t}(15 ; 22)(\mathrm{p} 11 ; \mathrm{q} 11)$ and clonal chromosomal changes $\mathrm{t}(13 ; 15)$ (p11;q13). D. Patient 4: t(1;9;22;3)(q24;q34;q11;q21). E. Patient 5: $\mathrm{t}(12 ; 22)(\mathrm{p} 13 ; \mathrm{q} 11)$. F. Patient $6: \mathrm{t}(4 ; 8 ; 9 ; 22)(\mathrm{q} 11 ; \mathrm{q} 13 ; \mathrm{q} 34 ; \mathrm{q} 11)$

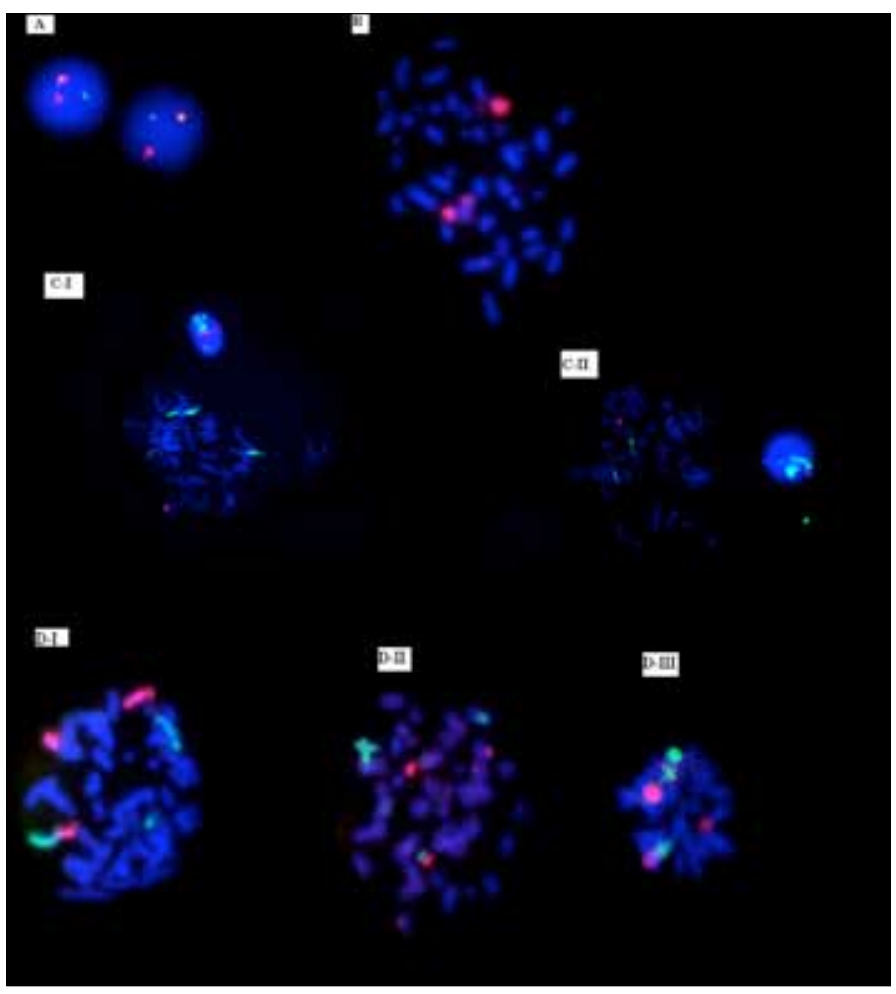

Figure 2. FISH analysis results. A. Signals of BCR-ABL fusion on interphase cells via the BCR-ABL1 D-FISH probe (ONCOR). Green signals on 1 of chromosome 9 , red signals on 1 of chromosome 22 , and yellow signals on the Ph chromosome showing BCR-ABL fusion. B. In patient 2 metaphase FISH showing $t(9 ; 22 ; 15)$ via WCP 15 (ONCOR) red signals. C. In patient 4 metaphase FISH showing $\mathrm{t}(1 ; 9 ; 22 ; 3)$ via WCP 1,9 , and 22 (MetaSystems). CI. Chromosome 1 is green and chromosome 22 is red. CII. and chhromosome 9 is green and chromosome 22 is red. D. In patient 6 metaphase FISH showing t( $4 ; 8 ; 9 ; 22)$ via WCP 4 and 8 , (Cytocell), and WCP 9 and 22 (MetaSystems). DI. Chromosome 4 is green and chromosome 8 is red. DII. Chromosome 4 is green and chromosome 22 is red. DIII. Chromosome 8 is red and chromosome 9 is green 
kemias and solid tumors, but the gene in $8 \mathrm{q} 13$ is unknown [20]. Band 7p22 in patient 1 corresponded to the map location of common fragile sites [21].

Among the 6 presented patients, 3 had simple and 3 had complex variant $\mathrm{Ph}$ translocations. To the best of our knowledge only a few cases of variant Ph translocations involving $>3$ chromosomes have been reported [1,5,9,11-19,22,23]. In all, 2 of the presented patients (4 and 6) had 4-way rearrangement [t(1;9;22;3)(q24;q34;q11;q21) and $\mathrm{t}(4 ; 8 ; 9 ; 22)$ (q11;q13;q34;q11)], including breakpoints that differed from those previously reported. CML studies reported 1q24 and 3q21 in simple and 3-way variant $\mathrm{Ph}$ translocations $[8,20]$. The literature does not contain any reports of 4-way complex translocations involving the chromosomal band 1q24 in CML patients. Similarly, simple and complex variant $\mathrm{Ph}$ translocations involving chromosomal bands $4 \mathrm{q} 11$ and $8 \mathrm{q} 13$ have not yet been reported in CML patients. In CML patients $8 \mathrm{q} 13$ has been reported in translocations other than $\mathrm{Ph}$ and $4 \mathrm{q} 11$ was reported in association with ANLL [8,18,20]. Specific chromosomal abnormalities involving band 3q21 have been observed in all FAB subtypes of acute myeloid leukemia (AML), in myelodysplastic syndrome, occasionally in the blastic phase of chronic myeloid leukemia, and rarely in chronic phase CML.

In some older studies variant $\mathrm{Ph}$ translocations involving $3 \mathrm{q} 21$ were considered a marker of poor prognosis in CML, and were used to justify the necessity of increasing the dose of imatinib, as commonly administered in the accelerated phase [24]. Patient 4 in the present study did not have a hematological or cytogenetic response to imatinib. Consequently, imatinib was replaced by dasatinib, which was administered for 1 year, but also did not result in a cytogenetic or hematological response. Excluding patient 3, all the presented patients with variant $\mathrm{Ph}$ translocations were poor responders to imatinib and were therefore treated with dasatinib.

Table 3. Chromosomes involved in variant $\mathrm{Ph}$ translocations in the 6 patients and previously reported breakpoints

\begin{tabular}{|c|c|c|}
\hline Chromosomes seen in our cases & Type of translocations reported in the literature & Reference \\
\hline 4p14, 14q32 & $\mathrm{t}(4 ; 14 ; 9 ; 22)(\mathrm{p} 14 ; \mathrm{q} 32 ; \mathrm{q} 34 ; \mathrm{q} 11)$ & Aoun et al. 2004 [1] \\
\hline $6 q 25,8 q 22$ & t(6;8;9;22)(q25;q22;q34;q11) & Acar et al. 1997 [9] \\
\hline $1 \mathrm{p} 36$ & $\mathrm{t}(1 ; 9 ; 22)(\mathrm{p} 36 ; \mathrm{q} 34 ; \mathrm{q} 11)$ & \multirow{4}{*}{ Yehuda et al. 1999 [5] } \\
\hline $3 p 25$ & $\mathrm{t}(3 ; 9 ; 22)(\mathrm{p} 25 ; \mathrm{q} 34 ; \mathrm{q} 11)$ & \\
\hline $4 \mathrm{p} 14$ & $\mathrm{t}(4 ; 9 ; 22)(\mathrm{p} 14 ; \mathrm{q} 34 ; \mathrm{q} 11)$ & \\
\hline $12 q 22$ & $\mathrm{t}(9 ; 22 ; 12)(\mathrm{q} 34 ; \mathrm{q} 11 ; \mathrm{q} 22)$ & \\
\hline $7 q 22$ & $t(7 ; 9 ; 22)(q 22 ; q 34 ; q 11)$ & \multirow[t]{2}{*}{ Zagariaa et al. 2004 [4] } \\
\hline $8 \mathrm{q} 12$ & $\mathrm{t}(8 ; 9 ; 22)(\mathrm{q} 12 ; \mathrm{q} 34 ; \mathrm{q} 11)$ & \\
\hline $3 q 26$ & $\mathrm{t}(3 ; 9 ; 22)(\mathrm{q} 26 ; \mathrm{q} 34 ; \mathrm{q} 11)$ & \multirow{3}{*}{ Morel et al. 2003 [10] } \\
\hline $4 \mathrm{p} 14$ & $\mathrm{t}(4 ; 9 ; 22)(\mathrm{p} 14 ; \mathrm{q} 34 ; \mathrm{q} 11)$ & \\
\hline $4 p 16$ & $\mathrm{t}(4 ; 9 ; 22)(\mathrm{p} 16 ; \mathrm{q} 34 ; \mathrm{q} 11)$ & \\
\hline $6 \mathrm{p} 22,12 \mathrm{q} 13$ & $\mathrm{t}(6,9 ; 12 ; 22)(\mathrm{p} 22 ; \mathrm{q} 34 ; \mathrm{q} 13 ; \mathrm{q} 11)$ & Zagariaa et al. 2006 [11] \\
\hline $1 \mathrm{q} 36$ & $\mathrm{t}(1 ; 22)(\mathrm{q} 36 ; \mathrm{q} 11)$ & \multirow{5}{*}{ Zang et al. 1993 [12] } \\
\hline $4 q 31$ & $\mathrm{t}(4 ; 9 ; 22)(\mathrm{q} 31 ; \mathrm{q} 34 ; \mathrm{q} 11)$ & \\
\hline $7 q 12$ & $\mathrm{t}(7 ; 9 ; 22)(\mathrm{q} 31 ; \mathrm{q} 34 ; \mathrm{q} 12)$ & \\
\hline $12 \mathrm{q} 24.1$ & $\mathrm{t}(9 ; 22 ; 12)(\mathrm{q} 34 ; \mathrm{q} 11 ; \mathrm{q} 24.1)$ & \\
\hline $3 q 26.2,17 q 21$ & $\mathrm{t}(3 ; 17 ; 9 ; 22)(\mathrm{q} 26.2 ; \mathrm{q} 21 ; \mathrm{q} 34 ; \mathrm{q} 11)$ & \\
\hline $1 \mathrm{p} 36$ & $\operatorname{der}(1) \mathrm{t}(1 ; 9 ; 22)(\mathrm{p} 36.1 ; \mathrm{q} 34 ; \mathrm{q} 11.2)$ & \multirow{7}{*}{ Reddy et al. 2000 [13] } \\
\hline $1 q 42$ & $\mathrm{t}(1 ; 9 ; 22)(\mathrm{q} 42 ; \mathrm{q} 34 ; \mathrm{q} 11.2)$ & \\
\hline \multirow[t]{2}{*}{$7 \mathrm{q} 11.2$} & $\operatorname{der}(9 ; 22 ; 7) \operatorname{ins}(7 ; 22)(q 11.2 ; q 11 \mathrm{q} .12)$ & \\
\hline & $\mathrm{t}(9 ; 22 ; 7)(\mathrm{q} 34 ; \mathrm{q} 11.2 ; \mathrm{q} 11.2)$ & \\
\hline 12 p13 & $\mathrm{t}(9 ; 22 ; 12)(\mathrm{q} 34 ; 11.2 ; \mathrm{p} 13)$ & \\
\hline $15 q 15,21 q 11.2$ & $\mathrm{t}(9 ; 22 ; 15 ; 21)(\mathrm{q} 34 ; \mathrm{q} 11.2 ; \mathrm{q} 15 ; \mathrm{q} 11.2)$ & \\
\hline 1q25, 20q13, 1p35 & $\mathrm{t}(1 ; 20 ; 9 ; 22 ; 1)(\mathrm{q} 25 ; \mathrm{q} 13 ; \mathrm{q} 34 ; \mathrm{q} 11.2 ; \mathrm{p} 35)$ & \\
\hline
\end{tabular}


Table 3. Continued

\begin{tabular}{|c|c|c|}
\hline Chromosomes seen in our cases & Type of translocations reported in the literature & Reference \\
\hline $1 \mathrm{p} 36$ & $\mathrm{t}(1 ; 9 ; 22)(\mathrm{p} 36.1 ; \mathrm{q} 34 ; \mathrm{q} 11.2)$ & \multirow{5}{*}{ Costa et al. $2006[14]$} \\
\hline $1 \mathrm{q} 21$ & $\mathrm{t}(1 ; 9 ; 22)(\mathrm{q} 21 ; \mathrm{q} 34 ; \mathrm{q} 11.2)$ & \\
\hline $12 \mathbf{p} 13$ & $t(9 ; 22 ; 12)(q 34 ; q 11.2 ; p 13)$ & \\
\hline $12 q 13$ & $\mathrm{t}(9 ; 22 ; 12)(\mathrm{q} 34 ; \mathrm{q} 11.2 ; \mathrm{q} 13)$ & \\
\hline $12 p 13,20 q 12$ & $\mathrm{t}(9 ; 22 ; 20 ; 12)(\mathrm{q} 34 ; \mathrm{q} 11.2 ; \mathrm{q} 12 ; \mathrm{p} 13)$ & \\
\hline $1 \mathrm{p} 36$ & $\mathrm{t}(1 ; 9 ; 22)(\mathrm{p} 36 ; \mathrm{q} 34 ; \mathrm{q} 11)$ & \multirow{4}{*}{ Markovic et al. 2000 [15] } \\
\hline $3 p 11$ & $\mathrm{t}(3 ; 9 ; 22)(\mathrm{p} 11 ; \mathrm{q} 34 ; \mathrm{q} 11)$ & \\
\hline $3 q 12$ & $\mathrm{t}(3 ; 9 ; 22)(\mathrm{q} 12 ; \mathrm{q} 34 ; \mathrm{q} 11)$ & \\
\hline $4 q 12$ & $\mathrm{t}(4 ; 9 ; 22)(\mathrm{q} 12 ; \mathrm{q} 34 ; \mathrm{q} 11)$ & \\
\hline $1 \mathrm{p} 36,11 \mathrm{p} 15 \mathrm{q} 23$ & $\mathrm{t}(1 ; 11 ; 22)(\mathrm{p} 36.2 ; \mathrm{p} 15 \mathrm{q} 13 ; \mathrm{q} 12)$ & Babicka et al. 2006 [16] \\
\hline $4 q 34$ & $\mathrm{t}(4 ; 9 ; 22)(\mathrm{q} 34 ; \mathrm{q} 34 ; \mathrm{q} 11)$ & \multirow{20}{*}{ Reid et al. 2003 [17] } \\
\hline $1 \mathrm{p} 36$ & $\mathrm{t}(1 ; 9 ; 22)(\mathrm{p} 36 ; \mathrm{q} 34 ; \mathrm{q} 11)$ & \\
\hline $1 \mathrm{q} 32$ & $\mathrm{t}(1 ; 9 ; 22)(\mathrm{q} 32 ; \mathrm{q} 34 ; \mathrm{q} 11)$ & \\
\hline $1 \mathrm{q} 42$ & $\mathrm{t}(1 ; 9 ; 22)(\mathrm{q} 42 ; \mathrm{q} 34 ; \mathrm{q} 11)$ & \\
\hline $3 p 21$ & $\mathrm{t}(3 ; 9 ; 22)(\mathrm{p} 21 ; \mathrm{q} 34 ; \mathrm{q} 11)$ & \\
\hline $3 q 21$ & $t(3 ; 22)(q 21 ; q 11)$ & \\
\hline $4 p 14$ & $\mathrm{t}(4 ; 9 ; 22)(\mathrm{p} 14 ; \mathrm{q} 34 ; \mathrm{q} 11)$ & \\
\hline $4 p 16$ & $\mathrm{t}(4 ; 22)(\mathrm{p} 16 ; \mathrm{q} 11)$ & \\
\hline $4 q 31$ & $\mathrm{t}(4 ; 9 ; 22)(\mathrm{q} 31 ; \mathrm{q} 34 ; \mathrm{q} 11)$ & \\
\hline $7 q 11$ & $\mathrm{t}(7 ; 9 ; 22)(\mathrm{q} 11 ; \mathrm{q} 34 ; \mathrm{q} 11)$ & \\
\hline 7q32 & $\mathrm{t}(7,9,22)(\mathrm{q} 32 ; \mathrm{q} 34 ; \mathrm{q} 11)$ & \\
\hline $12 \mathrm{p} 12$ & $\mathrm{t}(12 ; 22)(\mathrm{p} 12 ; \mathrm{q} 11)$ & \\
\hline $12 q 13$ & $\mathrm{t}(9 ; 22 ; 12)(\mathrm{q} 34 ; \mathrm{q} 11 ; \mathrm{q} 13)$ & \\
\hline $12 q 14$ & $\mathrm{t}(9 ; 22 ; 12)(\mathrm{q} 34 ; \mathrm{q} 11 ; \mathrm{q} 14)$ & \\
\hline $15 q 15$ & $\mathrm{t}(9 ; 22 ; 15)(\mathrm{q} 34 ; \mathrm{q} 11 ; \mathrm{q} 15)$ & \\
\hline $15 q 15$ & $\mathrm{t}(15 ; 22)(\mathrm{q} 15 ; \mathrm{q} 11)$ & \\
\hline $15 q 24$ & $\mathrm{t}(9 ; 22 ; 15)(\mathrm{q} 34 ; \mathrm{q} 11 ; \mathrm{q} 24)$ & \\
\hline $5 q 13,7 q 11$ & $\mathrm{t}(5 ; 7 ; 9 ; 22)(\mathrm{q} 13 ; \mathrm{q} 11 ; \mathrm{q} 34 ; \mathrm{q} 11)$ & \\
\hline $6 q 24,8 q 24$ & $\mathrm{t}(6 ; 9 ; 22 ; 8)(\mathrm{q} 24 ; \mathrm{q} 34 ; \mathrm{q} 11 ; \mathrm{q} 24)$ & \\
\hline $7 q 22,15 q 14$ & $\mathrm{t}(7 ; 9 ; 22 ; 15)(\mathrm{q} 22 ; \mathrm{q} 34 ; \mathrm{q} 11 ; \mathrm{q} 14)$ & \\
\hline $4 q 12$ & $\mathrm{t}(4 ; 22)(\mathrm{q} 12 ; \mathrm{q} 11)$ & Baxter et al. 2002 [18] \\
\hline $4 q 25$ & $\mathrm{t}(4 ; 9 ; 22)(\mathrm{q} 25 ; \mathrm{q} 34 ; \mathrm{q} 11)$ & Sheth et al. 2005 [19] \\
\hline
\end{tabular}

Note. The same breakpoints with ours that involved in variant $\mathrm{Ph}$ translocations in literature were marked by bold character

The strongest evidence for serial stepwise rearrangements resulting in variant $\mathrm{Ph}$ translocation comes from the rare observation of patients with a standard $\mathrm{Ph}$ in 1 clone and a complex variant $\mathrm{Ph}$ in another clone, as in patient 4 in the present study, who had 1 clone with $\mathrm{t}(9 ; 22)(\mathrm{q} 34 ; \mathrm{q} 11)$ and 1 clone with a complex variant $\mathrm{Ph}$ translocation $\mathrm{t}(1 ; 9 ; 22 ; 3)(\mathrm{q} 24 ; \mathrm{q} 34 ; \mathrm{q} 11 ; \mathrm{q} 21)$. Cytogenetic evidence suggests that complex Ph translocation is derived from simple $\mathrm{Ph}$ translocation [17,25].
The breakpoints of variant $\mathrm{Ph}$ translocations in CML patients may be important, as they are associated with carcinogenesis. Above all, monitorization of chromosomes and localization of precise breakpoints involved in the complex rearrangements in CML patients will improve our understanding of the genetic mechanisms that play a role in the progression of malignant disease. We trust that the present study's results will contribute to the scientific com- 
munity's knowledge of CML cytogenetics. Written informed consent was obtained from all the patients.

\section{Conflict of interest statement}

The authors of this paper have no conflicts of interest, including specific financial interests, relationships, and/or affiliations relevant to the subject matter or materials included.

\section{References}

1. Aoun P, Pickering D, Foran J, Rasheed H, Wiggins M, Pavletic SZ, Sanger W. Interphase fluorescence in situ hybridization studies for the detection of 9q34 deletions in chronic myelogenous leukemia : a practical approach to clinical diagnosis. Cancer Genet Cytogenet 2004;154:138-43.

2. Stopera SA, Ray M, Riordan D, Christie N, Wickstrom D. Variant Philadelphia translocations in chronic myeloid leukemia: correlation with cancer breakpoints, fragil sites and oncogenes. Cancer Lett 55:249-53.

3. Lazarevic V, Jankovic G, Kraguljac N, Djordjevic V, Miljic P, Bogunovic M, Rajic Z, Cemerikic-Martinovic V, Suvajdzic N, Colovic M. Clinical, Immunophenotypic and Cytogenetic Features of Megakaryocytic Blast Crisis of Chronic Myeloid Leukemia: A Single Institution Study. Turk J Haematol 2001;18:107-15.

4. Zagaria A, Anelli L, Albano F. A fluorescence in situ hybridization study of complex $\mathrm{t}(9 ; 22)(\mathrm{q} 34 ; \mathrm{q} 11)$ in two chronic myeloid leukemia cases with in a masked Philadelphia choromosome. Cancer Genet Cytogenet 2004;150:81-5.

5. Yehuda O, Abeliovich D, Ben- Neriah S, Sverdlin I, Cohen R, Varadi $\mathrm{G}$ et al. Clinical implications of Fluorescence In Situ Hybridization Analysis in 13 Chronic Myeloid Leukemia Cases: Ph-Negative and Variant Ph-positive. Cancer Genet Cytogenet 1999;114:100-7.

6. Yunis J. Comparative analysis of high resolution chromosome techniques for leukemia bone marrows. Cancer Genet Cytogenet 1982;7:43-50.

7. Shaffer LG, Tommerup N. (eds) ISCN: An International system for Human Cytogenetic Nomenclature International Standing Committee on Human Cytogenetic Nomenclature. In: Neoplasia, Basel: S. Karger, 2005. pp. 88-95.

8. Mitelman F, Johansson B, Mertens F. Mitelman database of chromosome aberrations in cancer. Available from: http:/www.cgap. nci.nih.gov/Chromosomes/ Mitelman. Accessed 23 February 2009.

9. Acar H, Stewart J, Boyd E, Connor MJ. Identification of Variant Translocations in Chronic Myeloid Leukemia by Fluorescence In Situ Hybridization. Cancer Genet Cytogenet 1997;93:115-8.

10. Morel F, Herry A, Le Bris MJ. Contribution of fluorescence in situ hybridization analyses to the characterization of masked and complex Philadelphia chromosome translocations in chronic myelocytic leukemia. Cancer Genet Cytogenet 2003;147:115-20.
11. Zagariaa A, Anellia L, Albanob F, Vicaric L, Schiavoned E $\mathrm{M}$, Annunziatad M et al. Molecular cytogenetic characterization of deletions on der(9) in chronic myelocytic leukemia. Cancer Genet Cytogenet 2006;167:97-102.

12. Zhang J, Meltzer P, Jenkins R, Guan X-Y, Trent J. Application of Chromosome Microdissection Probes for Elucidation BCR-ABL Fusion and Variant Philadelphia Chromosome Translocations of in Chronic Myelogenous Leukemia. Blood 1993;81:3365-71.

13. Reddy KS, Sulcova V. A FISH Study of Variant Philadelphia Rearrangements. Cancer Genet Cytogenet 2000;118:121-31.

14. Costa D, Carrio A, Madrigal I, Arias A, Valera A, Colomer $\mathrm{D}$ et al. Studies of complex Ph translocations in cases with chronic myelogenous leukemia and one with acute lymphoblastic leukemia. Cancer Genet Cytogenet 2006;166:89-93.

15. Markovic VD, Bouman D, Bayani J, Al-Maghrabi J, Kamel-Reid S, Squire JA. Lack of BCR/ABL reciprocal fusion in variant Philadelphia chromosome translocations: a use of double fusion signal FISH and spectral karyotyping. Leukemia 2000;14:1157-60.

16. Babicka L, Pavlistova L, Brezinova J, Zemanova Z, Ransdorfova S, Houskova L. Complex chromosomal rearrangements in patients with chronic myeloid leukemia. Cancer Genet Cytogenet 2006;168:22-9.

17. Reid AG, Huntly BJP, Grace C, Green AR, Nacheval EP. Survival implications of molecular heterogeneity in variant Philadelphia- positive chronic myeloid leukaemia. Br J Haematol 2003;121:19-27.

18. Baxter EJ, Hochhaus A, Bolufer P, Reiter A, Senent L, Cervera J , Moscardo et al. The $\mathrm{t}(4 ; 22)(\mathrm{q} 12 ; \mathrm{q} 11)$ in atypical hronic myeloid leukaemia fuses BCR to PDGFRA. Hum Mol Genet 2002;11:1391-7.

19. Sheth F J, Sheth JJ, Verhest A. A three way complex translocation $(4 ; 9 ; 22)$ in two patients with chronic myelocytic leukemia. J Cancer Res Ther 2005;1:108-10 (BRIEF COMMUNICATIONS).

20. Atlas of Genetics and Cytogenetics in Oncology and Haematology. Available from: URL http:// AtlasGeneticsOncology.org/

21. Huret JL, Tanzer J, Henry-Amar M. Aberrant breakpoints in chronic myelogenous leukemia; oncogenes and fragile sites. Hum Genet 1986;74:447-8.

22. Sessarego M, Fugazza G, Bruzzone R, Ballestrero A, Mıglıno M, Bacıgalupo A. Complex chromosome rearrangements may locate the bcr/abl fusion gene sites other 22q11. Haematologica 2000;85:35-9.

23. Reid A, Gribble SM, Huntly BJP, Andrews KM, Campbell L, Grace CD. Variant Philadelphia translocations in chronic myeloid leukaemia can mimic tpycal blastic crisis chromosome abnormalities or classic $\mathrm{t}(9 ; 22)$ : a report of two cases. Br J Haematol 2001;113:439-42.

24. Buda G, Orciuolo E, Galimberti S, Benedetti E, Caracciolo F, Cervetti G, Carulli G, Papineschi F, Petrini M. Complex translocation $\mathrm{t}(3 ; 9 ; 22)(\mathrm{q} 21 ; \mathrm{q} 34 ; \mathrm{q} 11)$ at diagnosis is a negative prognostic index in chronic myeloid leukemia. Leuk Res 2000;32:192-4.

25. Juan PME, Cardenas VJP, Jimenez EAV, Angulo MG, Flores MAE, Garcia JRG. A complex translocation $(9 ; 22 ; 16)(q 34 ; q 11.2 ; p 13)$ in chronic myelocytic leukemia. Cancer Genet Cytogenet 2005;157:175-7. 